\title{
"Gateway" City and Nexus Between Two Continents: The Port City of Algeciras
}

\section{CARolin Alfonso}

In recent years, "Algeciras" has become a metaphor for the so-called "Fortress Europe". Strategically located to the West of the Strait of Gibraltar, connecting the Mediterranean and the Atlantic worlds as well as dividing Europe and Africa, in times of rapidly developing global migration and communication it has found its firm place in the media as a site of Europe's attempts to secure its borders from the clandestine influx of African migrants. On the other hand, Algeciras has always been a point of departure of European travellers to imagined "exotic" destinations of the African world. But during the summer, European travellers are outnumbered by Moroccan migrants from Spain, France, Belgium and the Netherlands, taking the passage to Tangiers or Ceuta for home leave. ${ }^{1}$

Since the 1970s the port of Algeciras has also become an internationally important node for goods and cargo, developing into one of the leading Spanish ports (APBA 2006). This gave way to massive transformations of the port itself, such as relocating major port functions to deep water areas, and the improvement and enlargement of port facilities. In this respect, Algeciras has been experiencing processes of transition which have affected port cities throughout the world (Hoyle 1988). As a consequence, the waterfront areas have become objects of revitali-

1 It is estimated that in summertime over three million people travel the most important passageway between Spain and Morocco. According to the Port Authority of the Bay of Algeciras (APBA) in 2005 the regular passenger traffic came close to 5 million people and over 1 million vehicles were recorded (APBA 2006). 
sation programmes, which are partly welcomed and partly contested by the inhabitants of the adjacent zones. These processes represent a major challenge to both urban planners and the communities involved.

This paper aims at linking these two topics, by asking how migratory flows and the air of transience affect cultural practices and the reproduction of differences in the port areas of Algeciras. My paper is based on field data gathered in the old port quarter around the public market place, in spring 2003 and summer $2004 .^{2}$

Following a brief summary of the historical development of Algeciras and the port, I shall give a short description of actual characteristics, and problems in the old port quarter. I will then describe new revitalisation processes taking place in the waterfront area, linking them to recent developments in port-city relations.

\section{Algeciras as a port city: Historical outline}

Due to its strategic position bridging two continents and two seas, Algeciras has a long history of settlement. The city itself was founded in 711 under the Islamic dominion as Al Yazirat Al Hadra (la isla verde, the green island). It soon became one of the most important ports of the Córdoba Caliphate and, with the Caliphate's decline, it became an independent kingdom. King Alfonso XI conquered the city in the $14^{\text {th }}$ century, but soon afterwards it was reconquered by the Granadian ruler Mohammad V. Some years later, the city was abandoned and razed to the ground in a desperate defence. It was only at the end of the $18^{\text {th }}$ century that Algeciras resumed mentionable activities as a port city. The International Conference of Algeciras ${ }^{3}$ in 1906 marks the foundation of Algeciras as a port city and the beginning of an intense development, which still continues today. The initial construction of what later would become the quayside, and increased port activities including important subsistence contraband trade with Gibraltar, helped to mitigate the impacts of recession which had hit the whole country due to the political and economic isolation during the Franco Regime (Nohlen/Hildenbrand 2005: 21). All the same, the second and most important impulse took off in the late $1960 \mathrm{~s}$ with the implementation of the plan de industrialización, which included the settlement of heavy industries (petrol refineries, chemical plants as well as steel works) in the bay of Algeciras,

2 I wish to thank Henk Driessen and Waltraud Kokot for initially encouraging me to find my way to Algeciras.

3 In short, the aim of the conference was to convene the then world powers in Algeciras to discuss the future of Morocco. 
as an alternative to the closing of the gate to Gibraltar because of heavy conflicts between the Franco regime and the British government. Furthermore, the plan set precise goals for the development of the port and its facilities. The enlargement of the port coincided with the modernisation of port technologies on a global scale, when technological changes, in particular containerisation and computerisation, were to be seen as starting points for a new epoch in maritime development (Hoyle 1988).

In the following years, the industrial boom along with the extension of the port attracted both Spanish workers and labour migrants, leading to a somewhat chaotic and bumbling development of the city itself. Today, Algeciras is the most important Spanish port in terms of container handling, ranging among the top ten most important ports of the European Union (APBA 2006).

At present, Algeciras counts an estimated 110,000 inhabitants (2003) and is considered as the logistic and administrative centre of the administrative district of the Campo de Gibraltar. ${ }^{4}$

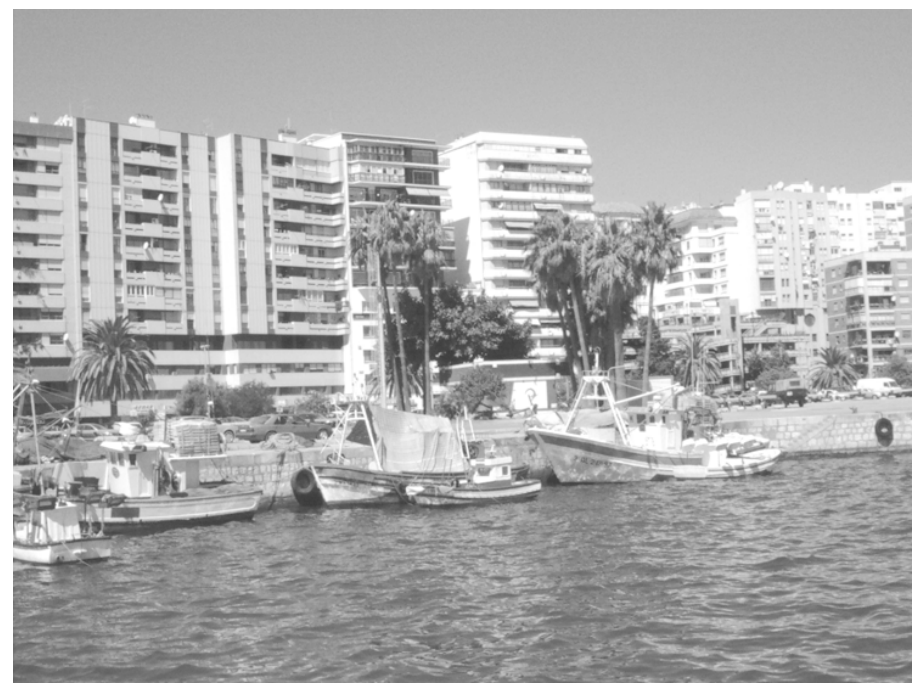

Fig. 1: Details of the Paseo Maritimo, where usually some fisher boat lie at anchor (photo: Carolin Alfonso)

Besides these commercial and financial activities, Algeciras has always been, and still is, considered a centre of a shadow economy and contra-

4 The administrative district encompasses Algeciras, Castellar, Gibraltar, Jimena, La Línea, Los Barrios, San Roque and Tarifa. 
band trade. While mainly alcohol and cigarettes were smuggled in the past, now rumours of illicit drugs and human trafficking are associated with the old port quarter around the market place Ingeniero Torroja.

According to the literature (cf. Driessen 2003), and confirmed by my interview partners, the city is characterised by an "air of transience". Algeciras is a place of transit with a strong port atmosphere: "El algecireño medio tiene un fuerte sentimiento de desarraigo" (Virgilio 10/08/2004). During my fieldwork, many Algecireños openly stated their perception of the city as being "fea, sucia y triste" 6 and complained about the bad maintenance of public spaces (parks, plazas, streets etc.) and of the city in general. This holds true especially for the areas along the waterfront, although changes began with the revitalisation processes attempting to regain obsolete port facilities as public space.

\section{The old port quarter}

"Algeciras no se ha convertido en pueblo ni en ciudad, sigue siendo un asentamiento de contrabandistas, psicológicamente quiero decir, y ese espíritu lo sufrimos desde en nuestra administración municipal hasta en la estética de nuestras calles." (Virgilio, 10/08/2004)

Immediately next to the port, i.e. along the Paseo de la Conferencia, port-related businesses and institutions are located. They include customs, ship and cargo insurance companies, ship outfitters as well as the port authority ("Autoridad Portuaria Bahía de Algeciras - APBA") and the "Centro de Formación Portuaria".

The old port quarter, also named the zona baja ${ }^{8}$ is situated adjacent to the waterfront (Paseo Maritimo), whose most striking feature is its depleted aspect. Compared to the "upper area" of the city, the houses in this area are dilapidated and the zona baja is perceived as a dangerous "no-go-area" by local (Spanish) inhabitants, an image reiterated in the media coverage and travelling guides as well.

5 "The average algecireño has a strong feeling of uprootedness." (All translations from Spanish original to English by the author).

6 Hideous, dirty and pathetic.

7 “Algeciras hasn't developed neither into village nor city, it continues to be a settlement of contrabandists, in a psychological manner I mean, and we still suffer from that spirit way down from our municipal administration to the aesthetic of our streets."

8 Lower zone. 
"El centro se ha convertido así en ese lugar incómodo al que hay que ir cuando no queda más remedio. Apenas tres o cuatro calles y la plaza principal dan una sensación de modernidad, animación y pulcritud, el resto parece abandonado, cierran bares y abren inmobiliarias, cierran tiendas y abren bancos, se tira un edificio histórico y se levanta un bloque horrendo, que a veces se queda por terminar." (Marcos, 04/04/2003)

Abandoned old buildings, new buildings never finished and badlymaintained public space in the streets and squares characterise the image of this area. Several of my interview partners claimed this to be part of a municipal strategy, which prioritises new housing and office development, rather than restoring the zona baja, and prevents potential financiers from investing in this area. As a result, the area has become unfavourable for local businessmen as well.

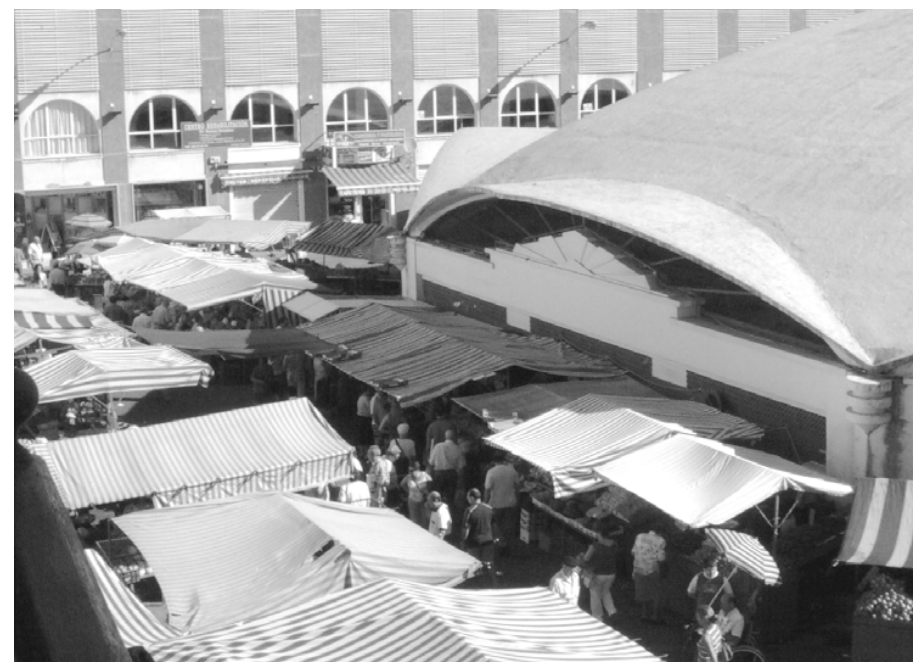

Fig. 2: The market place building Ingeniero Torroja surrounded by additional stalls (photo : Carolin Alfonso)

9 "This is how the centre has become an awkward place, to which to go when there's no remedy. Only three or four streets and the plaza central breathe an air of modernity, animation and tidiness, the rest seems to be abandoned, bars are closing and instead estate agent offices open up, shops are closing and instead a bank opens up, a historic building is torn down and a horrible multi-storey is being built, sometimes even never finished." 
The central market named after its constructor Ingeniero Torroja is located in the zona baja. Constructed in 1935, this building is famous as one of the most important works of Spanish architecture of the $20^{\text {th }}$ century and has become a local landmark for Algeciras. ${ }^{10}$ Algecireño merchants and inhabitants draw on this place as a symbol of local identity and pride, and it represents a shop window of Algeciras. The market consists primarily of fish and fresh produce stalls, and unlike its surroundings, the building and the stalls are well maintained. The building itself is surrounded by other stalls adding to the selection of fresh produce. Street vendors display their range of goods, mostly leather goods and cheap household articles. Most of these vendors are Spaniards, with a few Moroccans or Africans in between. Moroccan-run businesses are concentrated in the adjoining streets however, which are less attractive to Spanish investors and business interests.

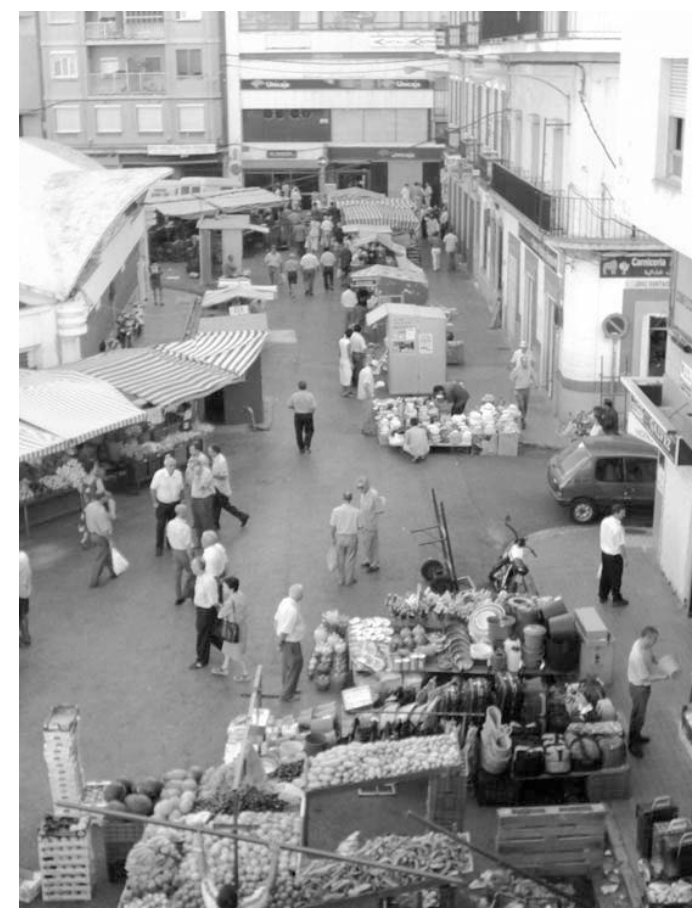

Fig. 3: Perspective on the market place on a weekday morning (photo: Carolin Alfonso)

10 A functional avant-garde work, it has an octagonal ground plan with no interior joist to support the ceiling. 
Except for the high season in summer, when the streets are crowded with ferry passengers waiting to cross the sea, Moroccan migrants are not strikingly visible in the general picture of the city. This might be due to the fact that most Moroccan (and other) migrants use Algeciras as a point of transit on their way to the major Spanish cities or to other countries of Western Europe. Pumares (2003: 189ff) alludes to this air of transience in his categorisation of migratory spaces in Spain and classifies Algeciras as a "border space". Because of its local geostrategical logic, Algeciras "es [...] un puente entre dos mundos que vive del flujo, del ir y venir entre ambos"11. (Pumares 2003: 189) ${ }^{12}$ This characterisation is somewhat confirmed - although with a negative connotation - by the statement of an informant: "Algeciras siempre se ha preocupado de que la gente se vaya y no que se quede"13 (Bhouziam 21/08/2004).

However, as Driessen (2003: 3) states, an increasing number of Moroccans have begun to settle down permanently. ${ }^{14}$ Along the way to the ferry terminals on the Avenida Virgen del Carmen (the Paseo Maritimo) there are plenty of ticket offices for the ferries to Ceuta or Tangiers, as well as small restaurants and fashion boutiques. Although there is no explicitly "Moroccan quarter" yet, nonetheless a process of appropriation of space is happening in the old port area. Here Moroccans are highly visible, especially on the Waterfront and in the streets around the market. The mosque is located here; young Moroccan men run Internet cafés and public telephone booths, as well as Moroccan bazaars selling fashion, leather goods and presents. Close by are groceries and halalbutchers, small restaurants, cafés and cheap hostels (hostales). Depending on the time of day, it is a lively shopping area characterised by ethnic businesses and the vibrant market activities, transforming into a more sombre mood in the evening hours.

11 "[...] a bridge between two worlds, which lives of the flow, the coming and going."

12 The other three spaces of his typology being agrarian spaces (insertion onto labour market with pre-industrial features), tourist spaces (hotel, catering and building sectors) and metropolitan spaces (highest concentrations of foreign population facing highly diverse incorporation into labour market) (Pumares 2003).

13 Algeciras always made an effort to see that people move on, and not that they stay put.

14 Generally speaking, Moroccan immigration to Spain remained low in numbers until the mid-1980s, considering Spain mainly as a transit country to e.g. France. This changed dramatically by the beginning of the 1990 s and nowadays Moroccans represent the main immigrant group in Spain (Aubarell 2004: 4; Mendoza 2001: 44). 
Lower rents in the run-down houses make the area affordable for migrants with limited economic means (Pumares 1996: 93ff; Martínez 1999). Besides economic aspects, Moroccans' access to housing is also limited by racist attitudes (Ribas-Mateos 2005: 132), which relegate them to dilapidated areas such as the zona baja.

This high concentration may be seen as indicator of an emerging ethnic infrastructure. Ethnic niches appear as a result of self-help and self-employment on the part of ethnic entrepreneurs (Kloosterman/Rath 2001: 194ff; Kloosterman/Rath 2003). Dense networks are not just part of an "imported" cultural practice, but at the same time an important basis of social organisation of Moroccan migrants in Algeciras. These networks help to recruit staff for businesses, providing socio-economic benefits for both parties involved, and furthermore offer protection and orientation in a new environment for newcomers. Such networks are characteristic of ethnic entrepreneurs and provide capital as well as employees (Mitchell 2003: 79; Light/Gold 2000: 94). In doing so, Moroccan migrants capitalise on their resources and oppose the limited local opportunity structures for business. By the appropriation of space in the waterfront and port areas, Moroccan migrants can rely on a dense transnational network of people and activities. Lately, a few Moroccanowned businesses have also opened in the "upper area" of the city, but this does not reach the density and presence of ethnic businesses in the port quarter.

Popular stereotypes of the area portray illicit drug-dealing, contraband and money laundering taking place there, cultivating an image of danger, which is also perpetuated in nearly all tourist guides. This image is intensified through vivid media coverage of complaints or infamous events, such as semi-hidden prostitution ${ }^{15}$ or conflicts between Spanish and Moroccan entrepreneurs (cf. Pérez 2004: 15).

\section{Revitalisation processes and relations between port and city}

While the port areas have remained dark, shabby and dilapidated for a long time, the City Council has recently joined forces with the port authority (APBA) and the Municipal Council of Planning ("Junta de Obras") to revitalise the waterfront and the neighbouring areas. These efforts were initiated in 2006 with the festivities celebrating the centen-

15 Low level prostitution is organised in low priced hostales surrounding the market place (Ribas-Mateos 2005: 107). 
ary of the International Conference of Algeciras, when history was evoked by exhibitions of antique photographs of the port, round table discussions, workshops and conferences focusing on the development of port-city relations (for detailed information see APBA 2005). One important achievement was the "creación de un programa de rehabilitación urbana de barrios con importante inmigración" 16 by the local authorities and associations of the Campo de Gibraltar. ${ }^{17}$ The area of the market place Ingeniero Torroja was especially scheduled for redevelopment, with plans for improving the pavement and illumination, as well as investments in more effective garbage collection and a higher presence of local police (García Iborra 2006). The most ambitious project however, is the Llano Amarillo, to let "[que] el mar vuelva de nuevo a penetrar en el gran Paseo Marítimo"18 (García Rojas 2006: 11) and bring about that "Algeciras vuelva a mirar al mar"19 (Ayuntamiento de Algeciras 2006: 14). The Llano Amarillo is a vast port area of more than $83,000 \mathrm{~m}^{2}$ situated on the Ribera quay of the fisher docks, which is planned to accommodate zones for leisure, commercial and sportive activities, as well as palm groves and a car park.

16 "Creation of a programme for the urban rehabilitation of quarters with important migration numbers."

17 Among others, the stated objectives of the ensuing rehabilitation programmes include:

“1. Conseguir una regeneración, mejora, refuerzo y potenciación, física y social, de los núcleos urbanos del área del Estrecho, con una especial atención a aquellas barriadas con una mayor densidad de población marroqui. (Achieve a regeneration, amelioration, reinforcement, potentiation, physically and socially of core urban areas of the Estrecho, with special attention to those quarters with a high number of migrant population.)

2. Disminuir la percepción de gheto, evitando el abandono de estas zonas por parte de la población autóctona, vertebrando física y socialmente los espacios urbanos con mayor densidad de dinámica migratoria. (Diminish the perception of ghetto, avoiding the local population to abandon those areas, forming a solid physical and social urban space in the areas with high migratory dynamics.)

3. Mejorar el espacio común, los equipamientos sociales y económicos y el mobiliario urbano. Tienen un carácter integrador en la zona de actuación. (Enhance the public space, as well as social and economic environment and the urban furnishing. They have an inclusionary character in the zones of action)." (Excelentísima Diputación Provincial de Cádiz)

18 "[that] the sea should penetrate the great Paseo Maritimo once again."

19 "Algeciras should be looking at the sea." 


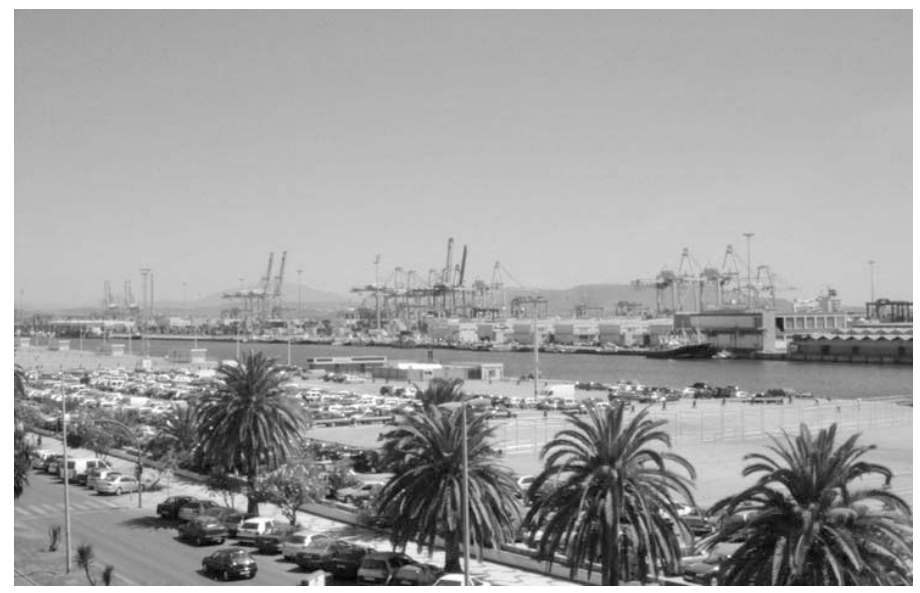

Fig. 4: Parts of the Llano Amarillo area with view to some port facilities in the back (photo: Carolin Alfonso)

The project aims at integrating this area into the unused spaces of the city and openly seeks to upgrade the maritime zone of the Waterfront. It is also intended to regain a $500 \mathrm{~m}$ wide area of the sea for an artificial beach, by relocating parts of the waterfront. This implies the removal of parking areas needed for shipping the vehicles of Moroccan migrants travelling home during the summers, which will be moved to another part of the city not so central. In addition, this project, which took off in autumn 2006 with a public invitation to compete for building development, seeks to connect with a project for revitalising the Rio de la Miel river, which - ironically - had been filled in decades ago in order to facilitate the enlargement of the port. By the way, this project has been named "El jardin de Umm Hakim", , alluding to the Islamic history of the city.

\section{Conclusion}

Algeciras is a paradigmatic example of exclusionary features of globalisation manifesting themselves in the local, where everyday dynamics of exclusion become especially evident in the access to appropriate housing. Since the 1970s, Moroccan migrants have settled their businesses in the port quarter. Among other reasons were derelict housing and the resulting low rents. The former Algeciran population had left the area.

20 "The garden of Umm Hakim". 
They were followed by the so-called gitanos, who allegedly left the place even more deteriorated. The port quarter's image as unsafe and dangerous made the area rather unpopular for investors and local businessmen, whose commercial activities were eventually taken over by Moroccan entrepreneurs targeting their fellow countrymen.

Public space has been defined as "the common ground where people carry out their functional and ritual activities that bind a community, whether in the normal routines of daily life or in periodic festivities" (Carr et al. 1992: xi). I have elaborated on the market area to emphasise its different meanings, day-to-day activities and various perspectives. The market emerges as an important place for the identity of the Algeciran population as well as for the public image of the city. The market place with its adjoining streets serves to highlight the appropriation of space by Moroccan migrants, who recur to social networks for ethnic entrepreneurship, preserving cultural practice based on solidarity networks.

Ostensibly the port quarter still remains run-down, but this perception does not hold true on closer examination. Given that the area was extremely neglected before the influx of Moroccan migrants, today in comparison the area offers vibrant commercial activities. Although illicit trade and camouflaged activities are supposed to take place there, all my interview partner agreed that an upgrading of the area has become increasingly visible. This process is far from concluded, and has received new impulses "from above" through the initiatives of the City Council and the Port Authority, as exemplified by the Llano Amarillo and the urban rehabilitation projects. In summary, the development of the old port quarter from a formerly well-off area, later inhabited by gitanos who were followed by Moroccan migrants and back to a proposed zone of urban leisure and consumption, represents an example of gentrification processes of the "invasion-succession type" (cf. Smith 1979; Ley 1986; Dangschat 1988; Hamnett 1991). It remains to be seen how plans aimed at bringing back the city to the waterfront will further affect the old port quarter and its local actors.

\section{References}

Aubarell, Gemma/Aragall, Xavier (eds.) (2003): Migración y desarrollo. Estudio de dos casos particulares: Ecuador y Marruecos, Madrid: Centro de Estudios de Cooperación al Desarrollo (CECOD).

Autoridad Portuaria de la Bahía de Algeciras - APBA (ed.) (2005): Centenario de la conferencia international de Algeciras y la junta de 
obras del puerto, Algeciras: Autoridad Portuaria de la Bahía de Algeciras.

Autoridad Portuaria de la Bahía de Algeciras -APBA (ed.) (2006): Memoria anual 2005, Algeciras: Autoridad Portuaria de la Bahía de Algeciras.

Ayuntamiento de Algeciras (ed.) (2006): "Llano amarillo. Algeciras vuelve a mirar al mar". Algeciras Hoy 1, p. 14.

Carr, Stephen/Francis, Marc/Rivlin, Leanne G./Stone, Andrew M. (1992): Public Space, Cambridge: Cambridge University Press.

Dangschat, Jens S. (1988): "Gentrification - Der Wandel innenstadtnaher Wohnviertel". In: Jürgen Friedrichs (ed.), Soziologische Stadtforschung. Sonderheft 29 der Kölner Zeitschrift für Soziologie und Sozialpsychologie, Opladen: Westdeutscher Verlag, pp. 272-292.

Driessen, Henk (2003): Preliminary Report: Enclavement of Moroccan Immigrants in the Port City of Algeciras, unpublished manuscript.

Excelentísma Diputación Provincial de Cádiz, Diputación de Cádiz (http://www.dipucadiz.es/iedt/maarifa/impActividades/impActividad .asp? ID=83) [09/07/2006].

García Iborra, Elisabeth (2006): "La generación del imposible. Algeciras, frontera de Europa”. El Dominical 09/06/2006.

García Roja, Rafael (2006): "Algeciras: Ciudad de centenarios". UCAmpus - Revista de la Universidad de Cádiz 1, pp. 11-14, (http://www.uca.es/web/organizacion/equipo_gobierno/dgcri/comuni cacion/revista) [01/09/2007].

Hamnett, Chris (1991): "The Blind Man and the Elefant: The Explanation of Gentrification". Transactions of the Institute of British Geographers 16 (2), pp. 173-189.

Hoyle, Brian (1988): "Development Dynamics at the Port-City Interface”. In: Brian S. Hoyle/David A. Pinder/M. Sohail Husain (eds.), Revitalising the Waterfront. International Dimensions of Dockland Redevelopment, London: Belhaven Press, pp. 3-19.

Kloosterman, Robert/Rath, Jan (2001): "Immigrant Entrepreneurs in Advanced Economies: Mixed Embeddedness Further Explored". Journal of Ethnic and Migration Studies 27 (2), pp. 189-201.

Kloosterman, Robert/Rath, Jan (eds.) (2003): Immigrant Entrepreneurs. Venturing Abroad in the Age of Globalization, Oxford et al.: Berg.

Ley, David (1986): "Alternative Explanations for Inner-City Gentrification”. Association of American Geographers 76 (4), pp. 521-535.

Light, Ivan/Gold, Steven J. (2000): Ethnic Economies, San Diego: Academic Press.

Martínez Veiga, Ubaldo (1999): Pobreza, segregación y exclusión espacial, Barcelona: Icaria. 
Mendoza, Cristóbal (2001): "Cultural Dimensions of African Immigrants in Iberian Labour Markets". In: Russell King (ed.), The Mediterranean Passage. Migration and New Cultural Encounters in Southern Europe, Liverpool: Liverpool University Press, pp. 41-65.

Mitchell, Bruce (2003): "The Role of Networks Among Entrepreneurs of Different Ethnic Groups”. The Small Business Monitor 1 (1), pp. 78-88.

Nohlen, Dieter/Hildenbrand, Andreas (eds.) $\left(2005^{2}\right)$ : Spanien. Wirtschaft - Gesellschaft - Politik. Ein Studienbuch, Wiesbaden: Verlag für Sozialwissenschaften.

Pérez, Rosario (2004): "Vecinos de la zona baja se quejan del deterioro cultural”. Europa Sur (18/08/2004).

Pumares, Pablo (1996): La integración de los inmigrantes marroquíes, Barcelona: Fundación 'La Caixa'.

Pumares, Pablo (2003): "La inmigración en España: Perspectivas desde el territorio". In: Gemma Aubarell (ed.), Perspectivas de la inmigración en España, Barcelona: Icaria, pp. 177-204.

Ribas-Mateos, Natalia (2001): Revising Migratory Context: The Mediterranean Caravanserai. In: Russell King (ed.), The Mediterranean Passage. Migration and New Cultural Encounters in Southern Europe, Liverpool: Liverpool University Press, pp. 22-40.

Ribas-Mateos, Natalia (2005): The Mediterranean in the Age of Globalization, New Brunswick: Transaction Publishers.

Smith, Neil (1979): "Toward a Theory of Gentrification: A Back to the City Movement by Capital not People". Journal of the American Planning Association 45 (4), pp. 538-548. 
